\title{
Isolated tuberculous pericarditis, an unusual presentation of tuberculosis - a case report
}

\author{
Raluca Jipa ${ }^{1 *}$, Mihaela Rădulescu ${ }^{1,2}$, Adriana Hristea ${ }^{1,2}$, Ruxandra Moroti ${ }^{1,2}$, Roxana Petre ${ }^{1}$, Raluca Dulamă ${ }^{1}$, \\ Doina Cristea', Victoria Aramă ${ }^{1,2}$ \\ From The 9th Edition of the Scientific Days of the National Institute for Infectious Diseases Prof Dr Matei \\ Bals \\ Bucharest, Romania. 23-25 October 2013
}

\section{Background}

Although during the past years a constant decreasing trend of extrapulmonary tuberculosis (TB) was registered in Romania, the number of reported cases of pericardial effusion TB remained steady at 40-50 cases annually, most of them in association with pleural effusion. Pericardial TB is a potentially lethal complication of $\mathrm{TB}$ and it is associated with high rates of morbidity and mortality.

\section{Case report}

We report the case of a 45 year-old man with a known history of psoriasis under biological treatment, diabetes mellitus type 2 and hypertension, admitted for fever and persistent cough for one week. No history of dyspnea, chest pain or hemoptysis was reported by the patient. According to the medical data, prior to the initiation of the biological therapy he had a positive Quantiferon test, and underwent 9 months of isoniazid prophylaxis. The chest X-ray showed an emphasized bilateral basal pulmonary drawing, predominantly on the left side. He has been treated with broad spectrum antibiotics but did not respond well. The echocardiography revealed a large pericardial effusion, with signs of incipient cardiac tamponade. Spiral computed tomography of the chest showed significant pericardial effusion ( $\sim 3.5 \mathrm{~cm}$ in thickness) all around the heart, but no active pulmonary lesions or pleural effusion. Pericardiocentesis was performed and 800 $\mathrm{mL}$ of blood stained fluid was drained. The pericardial fluid had a cell count of 3000 cells/cmm, with $95 \%$ lymphocytes and normal chemistry. Examination of the

\footnotetext{
* Correspondence: ralucajipa@yahoo.com

${ }^{1}$ National Institute for Infectious Diseases "Prof. Dr. Matei Balş", Bucharest, Romania

Full list of author information is available at the end of the article
}

pericardial biopsy specimen revealed granulomas. We initiated the anti-TB therapy, with good tolerance.

\section{Conclusion}

TB pericardial effusion remains an uncommon form of extrapulmonary $\mathrm{TB}$, but a high index of suspicion should be kept in mind, especially in immunocompromised patients.

\section{Authors' details}

${ }^{1}$ National Institute for Infectious Diseases "Prof. Dr. Matei Balş", Bucharest, Romania. ${ }^{2}$ Carol Davila University of Medicine and Pharmacy, Bucharest, Romania.

Published: 16 December 2013

doi:10.1186/1471-2334-13-S1-P84

Cite this article as: Jipa et al:: Isolated tuberculous pericarditis, an unusual presentation of tuberculosis - a case report. BMC Infectious Diseases 2013 13(Suppl 1):P84.

Submit your next manuscript to BioMed Central and take full advantage of:

- Convenient online submission

- Thorough peer review

- No space constraints or color figure charges

- Immediate publication on acceptance

- Inclusion in PubMed, CAS, Scopus and Google Scholar

- Research which is freely available for redistribution

Submit your manuscript at www.biomedcentral.com/submit
C Bïomed Central
C Biomed Central

(C) 2013 Jipa et al; licensee BioMed Central Ltd. This is an Open Access article distributed under the terms of the Creative Commons Attribution License (http://creativecommons.org/licenses/by/2.0), which permits unrestricted use, distribution, and reproduction in any medium, provided the original work is properly cited. 